\title{
Disaster and Relief Management - Katastrophen und ihre Bewältigung
}

\author{
Ed. by Angelika Berlejung \\ [Katastrophen und ihre Bewältigung.]
}

Veröffentlicht auf Englisch.

Dieser Band vereint die Vorträge der Internationalen Konferenz über Katastrophen und Katastrophenbewältigung im Alten

Disaster and Relief Management

Katastrophen und ihre Bewältigung

Edited by ANGELIKA BERLEJUNG

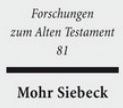

2012. VII, 544 Seiten. FAT 81

SBN 978-3-16-152015-0

DOI 10.1628/978-3-16-152015-0

eBook PDF 144,00€

ISBN 978-3-16-151706-8

Leinen $144,00 €$
Israel/Palästina, in Ägypten und im Alten Orient, welche von 4. Oktober bis 6. Oktober 2010 in Leipzig stattfand.

Wissenschaftler verschiedener Fachrichtungen untersuchen die Begrifflichkeit der Katastrophe in der Antike, den Einfluss von Katastrophen auf die Gesellschaft, die mögliche Dynamik und die kulturellen Auswirkungen. Sie geben Einblick in den derzeitigen Forschungsstand zur Destruktivität und Produktivität von Katastrophen in der Antike, einschließlich der Möglichkeit, dass Katastrophen als Topoi in ideologischen, mythologischen und theologischen Diskursen verwendet wurden. Die Beiträge in diesem Band bilden den ersten Schritt zu einer Kulturgeschichte der Katastrophen in der Antike.

Inhaltsübersicht

Introduction - Einleitung:

Angelika Berlejung: Disaster and Relief Management in Ancient Israel/Palestine, Egypt and the Ancient Near East. Katastrophen und Katastrophenbewältigung im Alten Israel/Palästina, in Ägypten und im Alten Orient

I. Theories of Disaster - Einblicke in theoretische Katastrophenforschung

Elke M. Geenen : Gesellschaftliche Verfügung über Kapitalien und Vulnerabilität in konzeptioneller Perspektive - Elisabeth List: Einbruch ins Selbstverständliche. Katastrophen als Kontingenzerfahrung - Jan Dietrich: Katastrophen im Altertum aus kulturanthropologischer und kulturphilosophischer Perspektive

II. Disaster and Relief Management in Israel/Palestine - Katastrophen und Katastrophenbewältigung im Alten Israel/Palästina II.1. Biblical Studies/Biblische Aspekte

Bernd Janowski : Eine Welt ohne Licht. Zur Chaostopik von Jer 4:23-28 und verwandten Texten - Sebastian Grätz : Gericht und Gnade. Die Fluterzählung im Rahmen der biblischen Urgeschichte - Thomas Römer: The Hebrew Bible as Crisis Literature Jacob L. Wright : Die Zerstörung des Ökosystems als Element der Kriegsführung im Alten Israel - Diana Edelman: Earthquakes in the Southern Levant. A Literary Topos and a Problem Requiring Architectural Solutions

II.2. Archaeological Studies/Archäologische Aspekte

Aren M. Maeir: Philistia and the Judean Shephelah after Hazael and the »Uzziah Earthquake«. The Power Play between the Philistines, Judahites and Assyrians in the 8th Century BCE in Light of the Excavations at Tell es-Safi/Gath - Aaron A. Burke: Coping with the Effects of War. Refugees in the Levant during the Bronze and Iron Ages - Gunnar Lehmann: Survival and Reconstruction of Judah in the Time of Manasseh - Ariel M. Bagg : Floods in the Desert. How Nabataeans Managed Catastrophes

III. Disaster and Relief Management in Egypt and the Ancient Near East - Katastrophen und Katastrophenbewältigung in Ägypten und im Alten Orient

Joachim F. Quack: Danaergeschenk des Nil? Zu viel oder zu wenig Wasser im Alten Ägypten - Ludwig D. Morenz : Hungersnöte im Bild. Zur Inszenierung von Topoi im Alten Ägypten - Paul A. Kruger: Disaster and the topos of the World Upside Down. Selected Cases from the Ancient Near Eastern World - Hanspeter Schaudig : Erklärungsmuster von Katastrophen im Alten Orient - Marco Stockhusen: Die Deutung kosmischer Erscheinungen am Beispiel von Sonnen- und Mondeklipsen. Ein Vergleich zwischen den Kulturräumen Mesopotamien und Ägypten im 1. Jt. v.Chr. - Jörg Klinger: Krankheit und Krieg im Spannungsfeld zwischen mythischer und realer Katastrophe

Angelika Berlejung is Professor for »History and Religion of Israel and its Environment « at the Faculty of Theology of the University of Leipzig, an Extraordinary Professor for Ancient Studies at the University of Stellenbosch/South Africa, a Visiting Full Professor for Biblical Archaeology at Bar Ilan University/lsrael, and a Full Member of the Saxon Academy of Sciences. https://orcid.org/0000-0002-4556-9167

etzt bestellen:

https://mohrsiebeck.com/buch/disaster-and-relief-management-katastrophen-und-ihre-bewaeltigung-9783161520150? no_cache=1

order@mohrsiebeck.com

Telefon: +49 (0)7071-923-17

Telefax: $+49(0) 7071-51104$ 